\title{
Disaster mitigation efforts based on community in coastal area of desa Berdaya Mirring
}

\author{
Nurmansyah ${ }^{1, *}$, Neneng Alghina Micha Grandisa ${ }^{1}$ \\ ${ }^{1}$ Rumah Zakat, Batu Kencana Street No.6, Bandung, Indonesia
}

\begin{abstract}
Indonesia is one of the countries that is categorized as a disaster-prone country. BNPB noted an increase in the number of disasters in Indonesia in the last 10 years, including earthquakes, volcanic eruptions to tidal waves and abrasion. West Sulawesi is one of the provinces prone to disasters, one of which is in Mirring Village, Polewali Mandar. Mirring Village is a coastal area that is prone to coastal abrasion and tidal waves, therefore the area is planted with mangroves to withstand tidal waves from the sea. Unfortunately, the people of Mirring village did not understand the function of the mangrove until finally Rumah Zakat through Relawan Inspirasi came to provide education regarding the use of mangroves, disaster mitigation to become a disaster-resilient family and an economically resilient family. This research is a descriptive study using a qualitative approach. The data collected with interview with 17 respondents. The results show that the community welcomes the community empowerment program towards a disasterresilient village by Rumah Zakat. The community has understood the function of mangroves and participated in disaster training to become disaster-resilient families. The community also initiated the existence of crab ponds and mangrove cultivation which later could become their source of income and form an economically resilient family.
\end{abstract}

\section{Introduction}

Every year, Indonesia experiences various natural disasters that occur one after another. This happens because geologically, Indonesia is located in the ring of fire, the path of volcanoes that surrounds the scope of the Pacific. Moreover, Indonesia is an archipelagic country that has a large sea and is located at the confluence of three plates; the Pacific, Indo-Australian and Eurasian plates:

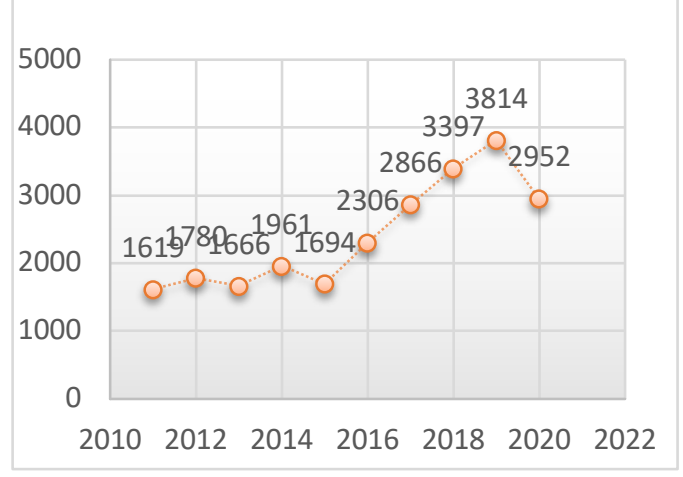

Fig. 1. Number of disasters in Indonesia 2010-2020 Source: https://gis.bnpb.go.id/, 2021

Figure 1 shows the number of disasters in Indonesia in the last 10 years. The number of disasters has increased quite high every year such as earthquakes, volcanic eruptions, forest fires, droughts, floods, landslides, cyclones and tidal waves and abrasion.

One of the natural disasters that was quite shocking was the tsunami in the Sunda Strait. The tsunami on December 22, 2018 occurred without earthquake, but was caused by volcanic activity, an underwater landslide on Mount Anak Krakatau. This is considered logical because volcanic eruptions can cause the mountain body to slide and the sea column to become unstable which results in rising the sea waves. Julius said that the Sunda Strait tsunami event reminded us that Indonesia is a disaster-prone country which is quite complex. Therefore, community preparedness training is needed.

Rumah Zakat as an NGO realizes the importance of community empowerment, both economically and socially. Indonesia as one of the disaster-prone countries needs to prepare its community for disaster preparedness training, especially those in coastal areas.

Desa Berdaya Rumah Zakat is one of the community empowerments programs, specifically for disaster mitigation, Rumah Zakat has a Disaster Resilient Village (Desa Tangguh Bencana), to form empowered and resilient communities in coastal areas

Desa Berdaya Mirring is one of the villages empowered by Rumah Zakat which is located in Tappina Hamlet, Polewali Mandar, West Sulawesi. This village is one of the areas prone to disasters, such as abrasion and tsunamis that occurred in other coastal

${ }^{*}$ Corresponding author: nurmansyah@desaberdaya.org 
areas. The following is a history of disasters in West Sulawesi.

Table 1. Disaster history in West Sulawesi.

\begin{tabular}{|c|l|l|}
\hline Year & \multicolumn{1}{|c|}{ Type of Disaster } & \multicolumn{1}{c|}{ Impact } \\
\hline 1967 & $\begin{array}{l}\text { 6.3 Magnitude } \\
\text { Earthquake and } \\
\text { Tsunami }\end{array}$ & 13 people died \\
\hline 1969 & $\begin{array}{l}\text { 6,9 Magnitude } \\
\text { Earthquake and } \\
\text { Tsunami }\end{array}$ & $\begin{array}{l}\text { 64 people died, 97 } \\
\text { were injured, 1287 } \\
\text { were damaged in } 4 \\
\text { villages. 4 m } \\
\text { Tsunami in } \\
\text { Pelattoang and 1.5 m } \\
\text { in Parasanga and } \\
\text { Palili }\end{array}$ \\
\hline 1983 & $\begin{array}{l}\text { 6,7 Magnitude } \\
\text { Earthquake }\end{array}$ & $\begin{array}{l}\text { No tsunami occurred } \\
\text { but many houses } \\
\text { were damaged }\end{array}$ \\
\hline \multirow{2}{*}{2018} & Coastal Abrasion & $\begin{array}{l}\text { In the last 10 years, } \\
\text { nearly 10 meters of } \\
\text { coastal area have } \\
\text { been eroded }\end{array}$ \\
\hline 2020 & $\begin{array}{l}\text { Residential } \\
\text { settlements along the } \\
\text { Polewali Mandar } \\
\text { coast are damaged }\end{array}$ \\
\hline heigh & $\begin{array}{l}107 \text { people died, } \\
3,369 \text { injured, 18,215 } \\
\text { houses damaged, } \\
70,496 \text { refugees }\end{array}$ \\
\hline
\end{tabular}

Source: Various News Sources, 2021

Desa Berdaya Mirring is surrounded by the ocean and has extensive mangroves. Even so, the surrounding community has not maximized the potential of the sea nor planting mangroves for people's lives, including for the community's economy. Not only that, public education about disasters is still very low, so disaster mitigation in the village is still lacking.

Various natural disasters that have occurred recently have made Indonesia the country with the second largest number of disaster victims in the world, namely 160 thousand people. Changes occurred in 2018, making Indonesia the first country with the most casualties [5]. Nugroho et al (2018), stated that the level of Indonesia's preparedness in dealing with disasters is still not optimal, this can be seen from the behavior of people who are still nervous during disaster evacuation.

This indicates that disaster communication through disaster mitigation still needs improvement. Mitigation is a continuous preventive action with the aim of reducing the impact of disaster risks that threaten life and property [6]. Mitigation efforts are not only the task of the government. Therefore, mitigation communication has a role to synergize policies between the government and non-government institutions involved in disaster management [3]

The central government, through BNPB (National Disaster Management Authority), encourages the formation of a strategy for the formation of a Disaster Resilient Village, which is contained in the Regulation of the Head of BNPB Number 1 of 2012 [1]. Furthermore, BNPB emphasized that efforts to reduce disaster risk are not only the task of the government, but also the direct involvement of individuals, families, and communitiesin dealing with disasters. Social values in society are the basic capital in the development of Disaster Resilient Village. An important step that must be taken is mapping the nature and characteristics of the area to understand the level of community capacity and vulnerability [4].

Therefore, Rumah Zakat present to support the government's efforts to improve community-based disaster mitigation communications in Desa Berdaya Mirring. Furthermore, the natural potential of Desa Berdaya Mirring, such as mangroves, can be used as one of the economic resources of the community so that they can create disaster-resilient families and economically resilient families.

The disaster that occurred caused a lot of losses, especially for the affected around the disaster location. Losses caused include loss of residence, property, life and affect the economy of the community. Moreover, people are still confused during the evacuation process and their understanding of disaster is still low. This requires serious efforts from the government and nongovernment institutions to anticipate a crisis. Therefore, the government and non-government institutions jointly carry out disaster mitigation programs, one of which is through the Disaster Resilient Village which is expected to form a disaster-resilient family and an economically resilient family.

\section{Purpose}

This study aims to determine community-based disaster mitigation process in Desa Berdaya Mirring assited by Rumah Zakat. In addition, the study will look at the process of Desa Berdaya Mirring assited by Rumah Zakat towards disaster-resilient families and economically resilient families.

\section{Method}

This study uses a qualitative approach. The type of research used is descriptive research using survey methods. The survey was conducted through interviews to obtain the necessary information. Interviews were conducted on 17 respondents consisting of 14 beneficiaries, 1 Relawan Inspirasi in Desa Berdaya Mirring, 1 Hamlet Head and Village Head. In addition, this study uses a study of documentation obtained from journals, books, news and other supporting documents. The study was conducted for approximately 3 months.

\section{Results}

Desa Berdaya Mirring is one of the villages located in Tappina Hamlet, Mirring Village, Binuang District, Polewali Mandar Regency and is located on the coast. As a village located on the coast, Desa Berdaya Mirring has abundant natural potential. In addition to natural potential, coastal areas are vulnerable to natural disasters such as abrasion and tsunami, this can be anticipated by planting mangroves around the coast. 
Initially, Desa Berdaya Mirring's community did not understand the function of mangrove planting as a disaster mitigation effort. In fact, $80 \%$ of the people make mountains as a source of life, they are quite afraid to get close to the sea. Whereas mangroves have many benefits if used properly, including for disaster mitigation and the economic life of the community.

This research uses Risk and Crisis Communication Management Theory from Matthew Seeger and the concept of disaster mitigation from George D. Haddow and Kim S. Haddow. The combination of these two theories can create disaster mitigation communication [7]. Two main things in disaster mitigation are program activities and communication strategies.

\subsection{Program activity}

One of the issues discussed in this research is the program activities carried out in Desa Berdaya Mirring as a Disaster Resilient Village. Desa Berdaya Mirring for the first time carried out a disaster mitigation communication program, in August 2020. Desa Berdaya Mirring was chosen as a Disaster Resilient Village because of its location around the Makassar Strait and as a coastal village that has mangroves but its sustainability is threatened due to damage caused by garbage and the people there who do not understand the function of mangrove planting.

Coastal communities do not understand that they have to maintain and cultivate mangroves, whereas this will protect them from disasters originating from the sea such as abrasion and tsunami. Mangroves can also have economic value for the community if they are processed into food. Several natural disasters that have occurred in Desa Berdaya Mirring include hurricanes, tidal winds and coastal abrasion. This disaster caused some damage which eventually moved people to start caring about the environment and disasters.

At first, the people of were afraid to approach the sea. They don't even understand the function of planting mangroves. Some people regard mangroves as shrubs and use them as firewood for sale. For their livelihoods and daily needs, $80-90$ percent of the people choose to go to the mountains which are quite far from their homes or go to the sea to look for fish. In addition, the community does not understand disaster mitigation at all. What should they do when a disaster strikes? Or signs when disaster will come.

Regarding to that, Rumah Zakat, which is represented by Relawan Inspirasi as a community mobilizer, has begun to carry out disaster mitigation activities. This disaster mitigation activity is not only the duty of the government or non-government institutions, but also need active participation of the community which is vital for the success of the disaster mitigation communication program.

The first thing that was done by Relawan Inspirasi was conducting socialization to several figures and the local government. This is carried to invite all parties to cooperate and actively participate in this disaster mitigation communication program. This initiation was welcomed by village leaders and local government.

The next step is socialization to the community with the assistance of several parties such as the Environment
Service, Forest Farmers Service and PMI. After the socialization, the First Emergency Training was conducted. This training is given to farmer groups because these groups are involved in mangrove cultivation. After the training, the farmer groups will provide training to their respective families. This farmer group consists of 35 people, if the assumption is that one family consists of two people, then a Disaster Resilient Family of 70 people will be formed.

The Disaster Resilient Family consist of 70 members will later become Agents of Change and provide public education about disaster resilience. There are three things that are included in the education and training component for families, namely the introduction of standby bags, directions for disaster evacuation and early warning signs.

In addition to forming a Disaster Resilient Family, Rumah Zakat has the initiative to form an Economic Resilient Family. It aims to form an independent and economically empowered community or family. Since the empowerment activity carried out in Desa Berdaya Mirring, the community welcomed it well, so that it is created smooth communication between Relawan Inspirasi and community. Relawan Inspirasi provides insight related to the economic potential in the growth and development of mangroves. This makes people do not need to go to the mountains or look for fish in the sea to meet their daily economic needs because later there will be a lot of marine life around the mangroves. To make this training a success, Relawan Inspirasi was assisted by several parties, one of which was a professor from Hasanuddin University, who assisted group members in crab cultivation. This is in line with the idea that emerged from the community to accelerate the process of crab cultivation around the mangrove area. Rumah Zakat hopes that the Empowered Village program in Mirring Village can increase public awareness about the importance of disaster prevention efforts in coastal areas and can form disaster-resilient families and economically resilient families.

\subsection{Communication strategy}

Communication strategy is important in disaster mitigation, in Perka BNPB No.1 of 2012 states that community-based disaster risk reduction places people living in disaster-prone areas as the main actors and actively participates in a sustainable and efficient manner. This means that local people know more about the nature around where they live, they also know the forms of activity of the community, therefore in this case we are bringing together local wisdom which we link with disaster mitigation activities. For example, in Mirring Village there is a season map where the community is busy with harvesting from their gardens in March, so we cannot carry out emergency first aid training activities in the water, but we can synchronize it with where they have a lot of activity, namely in the mountains. We also can't immediately change the habits of the people who mostly make a living in the mountains.

Besides that, the community is given the opportunity to monitor and evaluate the ongoing program. So, they welcome to this program. They are very cooperative and 
actively participate in this disaster mitigation activity. Relawan Inspirasi and the community regularly hold meetings every week to evaluate and discuss the next program to be carried out. In addition, several parties who were deemed to have an important role such as the Hamlet Head and the Village Head also supported the success of this activity.

Rumah Zakat is the only non-government institution involved in empowering and educating the community about disaster mitigation in Desa Berdaya Mirring. Relawan Inspirasi as the party appointed by Rumah Zakat assists the community in these various mitigation activities. The mitigation carried out involves the Department of the Environment for mangrove cultivation and PMI (Indonesian Red Cross) for disaster training. Desa Berdaya Mirring does not yet have social media or a Disaster Report application so all information is still conveyed directly through regular meetings or during training. The training is carried out on the sidelines of the community's free time so that it does not interfere with the community's economic activities.

Disasters can happen to anyone and anywhere. What we can do is reduce the risk of the impact by increasing the competence of the community through disaster training. There needs to be togetherness and

\section{References}

1. Buchari, A., Santoso, M. B., \& Marlina, N. (2017). Pengembangan Kapasitas Kelembagaan Desa Tangguh Bencana di Kabupaten Garut (Studi Kasus di Desa Pasawahan Kecamatan Tarogong Kaler). Jurnal Analisis Kebijakan dan Pelayanan Publik, 49-62.

2. Kumparan. (2018, Oktober 2). BNPB: Budaya Mitigasi Bencana Masyarakat Indonesia Lemah. Retrieved from https://kumparan.com/: https://kumparan.com/kumparannews/bnpbbudaya-mitigasi-bencanamasyarakat-indonesialemah-1538494508088227510

3. Lestari, P., Prabowo, A., \& Wibawa, A. (2012). Manajemen Komunikasi Bencana Merapi 2010 pada saat Tanggap Darurat. Jurnal Ilmu Komunikasi, 173-197.

4. Maarif, S., Damayanti, F., E, S. D., \& A, W. P. (2012). Initiation of the Desa Tangguh Bencana active participation from various parties, especially the community.

\section{Conclusion}

This study discusses efforts to improve communitybased disaster mitigation carried out in Desa Berdaya Mirring with the ultimate goal of forming a disasterresilient family and an economically resilient family. Rumah Zakat through Relawan Inspirasi makes several efforts in accordance with the combination of two theories: Risk and Crisis Communication Management and disaster mitigation. Steps taken by Relawam Inspirasi include socializing the importance of mangroves for disaster mitigation. Furthermore, the community is given training on mangrove cultivation and initiates the construction of crab ponds that can become an economic source for the community. The existence of crab pond innovation as a form of mangrove cultivation, is able to move the community to participate actively. In addition to socialization, Desa Berdaya Mirring has conducted emergency first aid exercises, especially for conditions around the sea as one of the efforts to increase public awareness and concern for disaster hazards.

Through Stimulus-Response Method. Indonesian Journal of Geography, 173-182.

5. Setyawan, F. A. (2019, Agustus 01). BNN Sebut Indonesia Nomor Wahid Jumlah Korban Bencana 2018. Retrieved from https://www.cnnindonesia.com/: https:/www.cnnindonesia.com/nasional/20190801 143833-20-417449/bnpb-sebut-indonesia-nomorwahid-jumlah-korban-bencana-2018

6. Wardyaningrum, D. (2014). Perubahan Komunikasi Masyarakat dalam Inovasi Mitigasi Bencana di Wilayah Rawan Bencana Gunung Merapi . ASPIKOM, 179-197.

7. Yunia, A., Pinariya, J. M., Forceila, D., \& Ivana, L. (2020). Program Berbasis Masyarakat dalam Upaya Pengurangan Risiko Bencana di Kabupaten Pandenglang. Journal of Communication Studies, 172-189. 